\title{
Seafood associated bacterial pathogens of public health significance: A brief review
}

\begin{abstract}
M. V. Ayyappan ${ }^{1}$ and T. C. Joseph ${ }^{1 *}$
${ }^{1}$ Microbiology, Fermentation and Biotechnology Division, ICAR-Central Institute of Fisheries Technology (CIFT), Cochin - 682 029, Kerala, India

Abstract

Seafood is perishable in nature and offers favourable medium for the growth of microorganism due to the presence of high content of water and nutrients. The absence of hygienic condition during production and processing results in proliferation of microorganisms thereby causing health risk to seafood handlers and consumers. The quality and safety of seafood is directly linked to the consumption of contaminated seafood. The potential hazards of microbial, chemical, or physical origin in farming, production, processing, or distribution stages, can compromise the quality of the product and becomes unacceptable for consumption. This review briefly describes the major seafood borne bacterial pathogens including emerging pathogens that can cause serious threat to food safety.
\end{abstract}

Key words: Bacteria, Contamination, Emerging pathogens, Quality, Seafood

\section{Highlights}

- The consumption of raw or partially cooked seafood causes potential health risk in human.

- Prevalence, pathogenicity and outbreak data of major seafood borne bacterial pathogens is reviewed.

- The emerging bacterial pathogens are enlisted with recent data supporting its occurrence in seafood.

- Preventive measures to illness depend on the extend of adherence to food safety procedures.

\section{Introduction}

Seafood is one of the most popular food consumed globally and its increasing demand is expected to grow to a value of $\$ 155.32$ billion by 2023 (Gbadegesin and Akintola, 2021). The increased demand of seafood had open up the marketing and consumption of ready to eat and ready to prepare products in recent years. The global fish production in 2018 was 178.5 million metric tons (FAO, 2020). The per capita consumption of seafood globally showed a hike from $9.0 \mathrm{~kg}$ in 1961 to $20.5 \mathrm{~kg}$ in 2018 with an increase of 1.5 percent per year (Sheng and Wang, 2021). It was reported that $88 \%$ of the global seafood production were utilized for direct human consumption and over $38 \%$ of them were traded internationally (FAO, 2020).

Globally seafood provides 20 percent of the per capita intake of animal proteins for around 3.3 billion people (FAO, 2020). Further, the sector provides livelihood to almost 60 million people worldwide (FAO, 2018). The diversified growth in aquaculture production in the Indian seafood sector accelerated the export of marine products to reach a value of Rs. 46662.85 crores during 2019 - 2020 (FAO, 2020). It has been reported that about $60 \%$ of the Indian population consumes fish and the per capita fish consumption pattern varies across the states with Tripura, Kerala, and Manipur ranking high with $29.29 \mathrm{~kg}, 19.41 \mathrm{~kg}$, and $14.1 \mathrm{~kg}$ respectively in 2019-2020 (Singh and Basudha, 2021). 
Seafood is generally considered microbiologically safe when cooked and offers several health benefits including reduction of cardiovascular diseases, contribution to improving bone strength and congenital developments in infants, reduction of joint pains and inflammations etc. (Ronzio, 2003). However, when the seafood is consumed in raw form as fresh, live, partially cooked etc. despite having these advantages, are associated with foodborne illness (Hicks, 2016). The introduction of advanced processing methods and value addition techniques with concomitant improvement in testing and diagnostics of its quality and safety enables the optimum utilization of seafood. The dynamic nature of seafood as well as the hike in seafood consumption increases the risk in foodborne disease outbreak worldwide which further led to the strict compliance of regulatory measures in terms of quality and safety, during marketing of fish and fishery products (Giusti et al., 2007). Several authors have reported the role of seafood as one of the major vehicles for the outbreak of foodborne diseases (Angelillo et al., 2000; Newell et al., 2010; Dumen et al., 2020).

There has been an increase in foodborne outbreaks worldwide. Approximately 48 million cases of foodborne diseases were reported annually from USA alone with around 1.28 lakh hospital cases and 3000 fatalities (Scallan et al., 2011). Fish was the single food category that was most commonly implicated $(17 \%)$ in the foodborne outbreaks (DeweyMattia et al., 2018). In India, out of 37 foodborne outbreaks during 1980 to 2009,24 of them were related to bacterial contamination in foods (Vemula et al., 2012). However, a significant increase in foodborne outbreaks from 2009 to 2018 contributing a total of 2688 cases with 1.5 lakh illness and 572 deaths and with 25 outbreaks due to consumption of seafood (Bisht et al., 2020). With the increase in sea food borne outbreaks, awareness regarding hygiene, waste management etc. has increased worldwide. Rapid industrialization has resulted in the release of sewage and other industrial effluents into natural water bodies, increasing the chances of sea food borne diseases (Bukola and Zaid, 2015). The seafood-borne outbreaks are mainly caused by bacteria, viruses and parasites (Iwamoto et al., 2010). Developed countries have database on foodborne outbreaks whereas developing countries are yet to have a reliable database due to lack of proper diagnostic facilities, faulty reporting system, inefficient database management and monitoring system (Callejon et al., 2015). There are limited reports on sea food borne outbreaks in India and the cases are often underreported (Saraswathi et al., 1989; D'Souza et al., 2018; Bisht et al., 2020).

Based on the ranking system given by Huss et al. (2000), seafood falls under three risk categories; high, medium and low. The highrisk category includes raw fish and shellfishes and frozen bivalves. The medium risk category includes the fresh and frozen fish and shell fishes to be consumed after cooking. Low risk categories include minimally processed fish and fishery products such as pasteurized and heat processed products. One of the major risks recognised for the contamination of seafood by pathogenic bacteria is by the exposure of food chain to contaminated water (Amagliani et al., 2012). The water runoff from polluted areas such as waste waters from agricultural, industrial and sewage will significantly change the microbial flora of the harvesting water bodies and culture ponds resulting in the contamination of seafood with pathogens like, pathogenic E. coli, Salmonella, Campylobacter etc. or viruses such as Hepatitis A, Norwalk etc. (Chua et al., 1989). The consumption of raw or partially cooked seafood especially bivalve molluscs can be one of the major contributing factors for the spread of sea food borne pathogens (Nair et al., 2007). Another reason for the spread of contaminating pathogens in seafood is the poor personal hygiene of workers and food handlers (Simon and Sanjeev, 2007). Inadequate storage temperature and use of poorquality raw material in the preparation of seafood etc. will increase the risk of illness due to bacteria (Kumar et al., 2015). Many of the 
pathogens grow rapidly at room temperature. Fish or fishery product left at an ambient temperature is easily spoiled and can get contaminated with pathogens (Feldhusen, 2000). This review describes the major microbial pathogens and food safety concerns associated with sea foods.

\section{Sea food borne pathogens}

Fish and fish products are rich in protein, essential fatty acids, vitamins and minerals which provide favourable conditions for the growth of bacteria. The microflora of seafood comprises both indigenous bacteria such as Vibrios, Pseudomanas, Shewanella etc. (Parlapani et al., 2013) as well as exogenic bacteria such as Escherichia coli, Staphylococcus aureus, Enterobacter aerogenes etc. (Boziaris and Parlapani, 2017; Gufe et al., 2019). The human pathogenic bacteria mainly belong to the second category. However, the native microflora of seafood and aquatic environments are reported as causative agents in diseases ( $\mathrm{Su}$ and Liu, 2007). The presence of such bacteria in seafood reflects the possible risk of transmission to the higher organisms, including humans.

The introduction of certain bacteria to the aquatic environment through anthropogenic activities is mainly associated with foodborne outbreaks (Rippey, 1994). The factor affecting the presence of such pathogens in fish are farming or capture procedures, ecological conditions, processing and distribution protocols followed etc. (Poli, 2005). Some pathogens such as Yersinia ruckeri can cause diseases only in aquatic animals (Fernandez et al., 2003). However certain bacteria can cause diseases in both aquatic animals and humans, such as Vibrio spp. (Igbinosa and Okoh, 2008), Aeromonas hydrophila (Daskalov, 2006) etc. The public health significant bacteria of seafood origin can transmit disease to human through fish and fishery products. The major human pathogenic bacteria associated with sea foods are Vibrio spp., Escherichia coli, Salmonella,
Listeria monocytogenes, Staphylococcus aureus, Clostridium botulinum, Yersinia spp., Bacillus cereus and Shigella spp. (Feldhusen, 2000).

Salmonella: Infection caused by Salmonella continues to be the major cause of sea food borne outbreaks globally. The main source of contamination is associated with raw oyster, salmon, tuna, value added products of tuna, sole etc (Amagliani et al., 2012; Kumar et al., 2015). Infection due to Salmonella causes gastrointestinal disease and typhoid fever in human (Hassan et al., 2018). Salmonella induced sea food borne outbreaks are reported from several countries worldwide (Brands et al., 2005; Iwamoto et al., 2010; Barret et al., 2017). Non typhoidal serovars are generally associated with sea food borne outbreaks. It was reported that USA alone contributes about 1 million cases of foodborne non typhoidal Salmonella infection globally (Hassan et al., 2018). Kumar et al. (2015) studied the growth dynamics of Salmonella in seafood by evaluating expression of genes related to virulence and stress at varying temperatures and reported that Salmonella could multiply at ambient temperature and $45^{\circ} \mathrm{C}$ with increased expression of virulence genes at room temperature. In India, the prevalence of Salmonella is high and ranged between $30.5 \%$ in fish to $34.1 \%$ in calms (Kumar et al., 2009). Prevalence rates of $20.7 \%$ have been reported in fish samples from Mumbai, India (Prabhakar et al., 2020). A recent study revealed S. Typhimurium in $7.9 \%$ of the aquaculture farms in Kerala (Greeshma et al., 2021). The prevalence rates were low in temperate countries such as US, Spain and Mexico, ranging from $1.5 \%$ to $16.4 \%$ (Martinez-Urtaza et al., 2004; Simental and Martinez-Urtaza, 2008; Setti et al., 2009; DePaola et al., 2010). The major serovars of Salmonella reported from seafood samples of fishing harbours and fish markets in Cochin, India were $S$. weltevreden, $\mathrm{S}$. rissen, $S$. typhimurium and $S$. derby (Kumar et al., 2009). Salmonella infection occurs either 
through the contact with infected animals, or through the consumption of contaminated sea foods. Antony et al. (2009) reported Salmonella Weltevreden outbreak in 34 students from Mangalore, India with fish being source of infection. In international seafood trade, about $1 \%$ of all rejections is due to Salmonella contamination in variety of seafood products such as fresh, frozen cooked and ready to eat products (Geetha et al., 2020). The refusals of import due to Salmonella in seafood formed $66 \%$ of the total import rejections to US during 2010-2015 (Rao et al., 2017).

The inspection practices for the monitoring of bacterial pathogen uses Listeria spp. and Salmonella spp. as target bacteria for the food products. The optimum cooking period for food including seafood is set with respect to Salmonella spp. as a target pathogen where the cooking period for the destruction of Salmonella will be sufficient for killing other suspected pathogens in the products (USFDA, 2008). Several countries have set zero tolerance for Salmonella spp. in food products including sea foods (Hastein et al., 2006)

Escherichia coli: Escherichia coli is a commensal bacterium commonly found in the intestinal tract of warm-blooded animals including humans. Hence, the presence of this bacterium in food products indicates faecal contamination (Visnuvinayagam et al., 2017). There are around 186 O-types and $57 \mathrm{H}$ serotypes of $E$. coli that are generally nonpathogenic in nature, however, there are certain pathotypes that are pathogenic to human being; enterohaemorrhagic E. coli (EHEC), enteropathogenic $E$. coli (EPEC), enterotoxigenic $E$. coli (ETEC), enteroinvasive E. coli (EIEC), enteroaggregative $E$. coli (EAEC), diffusely adherent E. coli (DAEC) and shiga toxinproducing E. coli (STEC). This classification is based on their $\mathrm{O}: \mathrm{H}$ antigen types, virulence characteristics and clinical syndromes (Toma et al., 2003). ETEC causes gastroenteritis in humans and low dose of toxin production is sufficient for the excessive fluid secretion and diarrhoea in humans as well as in infants (Beatty et al., 2006). EPEC causes infantile diarrhoea and the outbreak is mostly seen in least developed countries due to the poor sanitation and hygiene habits (Barlow et al., 1999). The STEC is highly virulent and is grouped under enterohaemorrhagic E. coli (EHEC). E. coli 0157:H7 of EHEC category cause diarrhoea and haemolytic uremic syndrome (HUS) in humans (DeCludt et al., 2000) and several infections have been reported in many parts of the world (Manna et al., 2006). The incidences of STEC in seafoods from Mangalore, India have been reported by Kumar et al. (2001). Thampuran et al. (2005) have isolated E. coli strains from finfish samples in retail markets in Cochin, India with the ability to produce haemolysis of human blood. However, typical E. coli $\mathrm{O} 157$ or other ST E. coli were not detected. Enterohaemorrhagic E. coli (EHEC) O157:H7 was isolated from Indian white shrimp, Fenneropenaeus indicus in retail fish markets of Cochin (Surendraraj et al., 2010). Virulence in STEC is due to the presence of virulence genes such as either stxl, or stx 2 , and both, ehxA and eae genes. The minimal dose of less than 100 cells is able to cause food poisoning in humans (Griffin and Tauxe, 1991). Roy et al. (2013) have reported the incidence of ETEC and EPEC from samples in shrimp farms of Pakistan and recommended good hygienic practices for controlling the occurrence of pathogenic E. coli. Wang et al. (2011) reported the presence of E. coli in $10.5 \%$ of imported samples sold in retail markets in Baton Rouge, Los Angeles, but did not detect the pathogenic strains. Canizalez-Roman et al. (2013) isolated EPEC strains from seafood samples from Mexico. Recently, several studies were reported from Cochin estuary regarding the presence of pathogenic and antibiotic resistant E. coli (Sukumaran and Hatha 2015; Divya and Hatha, 2019). Relatively high prevalence of ETEC (18.6\%) and EPEC (4.0\%) with low prevalence of STEC $(0.8 \%)$ among pathogenic E. coli (23.4\%) from seafood samples of different fish markets and landing 
centres of Kerala were reported (Murugadas et al., 2015). Antony et al. (2021) isolated of E. coli $\mathrm{O} 157$ from molluscan growing areas along the Indian coast with high prevalence of enterotoxigenic strains followed by other pathotypes such as EHEC, EPEC and EIEC.

Staphylococcus aureus: Staphylococcal foodborne illness is due to the consumption of food contaminated with membrane-damaging, invasive staphylococcal toxins (Murugadas et al., 2017). The presence of enterotoxigenic $S$. aureus in fishery products and fish processing environments have been reported from India (Simon and Sanjeev, 2007; Murugadas et al., 2017) and Korea (Rhee and Woo, 2010). Infection due to methicillin resistant Staphylococcus aureus (MRSA) is mostly hospital acquired and the high prevalence of this bacterium in health care sector is reported from all over the world (Gould, 2006; Carnicer-Pont et al., 2006). MRSA outbreak that resulted in mortalities were reported from Netherlands and banana was implicated as the source of infection (Kluytmans et al., 1995). The ingestion of contaminated shredded pork barbeque and coleslaw resulted in food poisoning outbreak due to MRSA in United States (Jones et al., 2002). The prevalence of $S$. aureus in Indian seafood ranged from 9 to $23 \%$ during the period from 1985 to 2016 (Simon and Sanjeev, 2007; Visnuvinayagam et al., 2015; Murugadas et al., 2016). The presence of MRSA in Indian seafood was first reported in 2015 in fish samples from Cochin and Mumbai coast by Visnuvinayagam et al. (2015). Later on, there were several reports of MRSA in seafood from India with incidence ranging from 6-11\% (Kumar et al., 2016; Murugadas et al., 2016). It is imperative to prevent the seafood contamination with MRSA by following strict personal hygiene and GMP from harvest of the raw material to the consumption of end product by the consumers.

Vibrio parahaemolyticus: The foodborne outbreaks caused by Vibrio parahaemolyticus are associated with consumption of raw, partially cooked seafood especially bivalve mollusc. This bacterium was first reported as an entero-pathogen in a foodborne outbreak in Japan in 1950 due to the consumption of partially cooked sardine (Fujino et al., 1953). Foodborne illness due to the presence of these bacteria has been frequently reported (Harakudo et al., 2003; Nair et al., 2007; Peng et al., 2010; Xu et al., 2016). The bacteria were detected in many seafood samples including eel, octopus, squid, shrimp, oyster, sardine, tuna, mackerel, perch, pompano etc. (Beuchat, 1982; Oliver and Kaper, 1997; Anjay et al., 2016).

Most of the environmental strains are nonpathogenic and does not cause any infections. Pathogenic strains are characterized by the presence of haemolysin genes such as $t d h$ and/ or trh gene (Okuda et al., 1997). Most of the pathogenic environmental strains carry trh gene whereas presence of $t d h$ gene is more in clinical strains that cause infection (Nair et al., 2007). Main symptoms of infection include gastroenteritis, wound infection and in rare cases, septicaemia can occur ( $\mathrm{Su}$ and Liu, 2007). No dominant serovars were involved in food poisoning until the appearance of O3:K6 pandemic serotype in India in 1996. Pandemic strains possess $t d h$ and are negative for $t r h$ and urease. Till now, around 75 different combinations of $\mathrm{O}$ and $\mathrm{K}$ serotypes of $V$. parahaemolyticus are reported (Ishibashi et al., 2000). Frequently isolated serovariants includes O4:K68, O1: KUT and O1:K25 (Matsumoto et al., 2000).

The incidence rate of $V$. parahaemolyticus in seafood ranges from 35 to $100 \%$ (Ayyappan et al., 2018; Narayanan et al., 2020a). Although the occurrence of O3:K6 in seafood in India has not been reported, its serovariants such as O10: KUT have been detected in seafood (Pal and Das, 2010). Recently, pandemic strains were isolated from clinical samples from Kolkata, India (Pazhani et al., 2014). Anjay et al. (2014) reported a high rate of prevalence of $V$. parahaemolyticus $(75.5 \%)$ in seafoods collected from different fish markets 
in Kolkata. Sudha et al. (2014) reported the presence of antibiotic resistant pathogenic $V$. parahaemolyticus strains from seafoods in Cochin, Kerala. Recent study suggested that marine water fish and shellfish samples from Kolkata harbors considerable percentages of pathogenic and pandemic strains of $V$. parahaemolyticus (Anjay et al., 2016). Ayyappan et al. (2018) have reported the presence of pathogenic $V$. parahaemolyticus with characteristics of pandemic clones from seafood and environmental samples of Mumbai, India. Multidrug resistant pathogenic $V$. parahaemolyticus carrying $t d h$ and trh genes were prevalent in shrimp aquaculture farms (Narayanan et al., 2020b). Presence of potentially pathogenic $V$. parahaemolyticus harbouring $t d h$ gene was reported from marine fishes sold in Kerala, India (Narayanan et al., 2020a).

Vibrio cholerae: The transmission route of $V$. cholerae to human is mainly through aquatic environments particularly water. There are reports of this pathogen in fish and fishery products from several parts of the world (Kumar and Lalitha, 2013; Joseph et al., 2015; Azarian et al., 2016). Several cases of rejections of consignments of seafood in international trade due to the presence of $V$. cholerae have been reported. Generally environmental strains are non-pathogenic and do not possess any virulence related genes such as ctx, zot, ace and tcpA (Sechi et al., 2000). The survival and evolutionary dynamics of $V$. cholerae in water causes the emergence of diverse sero and biovariants of $V$. cholerae due to gene transfer mechanisms (Azarian et al., 2016). The horizontal and lateral gene transfer mechanism causes the acquisition of virulence genes, antigenic types such as $\mathrm{O} 1$ and $\mathrm{O} 139$ etc. (Faruque et al., 2004). Toxigenic V. cholerae of classical biotype had been responsible for infections previously and many epidemic outbreaks were reported in the $19^{\text {th }}$ century which was gradually replaced with an emerging strain of the El Tor biotype in $20^{\text {th }}$ century (Nair et al., 2002). Re-emergence of classical biotype together with El Tor strains were reported in Bangladesh during 1982 (Samadi et al., 1983) and these strains were frequently reported in gastroenteritis and diarrhoea from the area until 1993. Another epidemic strain of $V$. cholerae carrying O139 antigen was first reported in 1992 in Southern Asia (Albert, 1994). The incidences of cholera due to O139 and O1 Biotype El Tor strains gradually increased thereafter in India and Bangladesh. Subsequently, the variant of O1 El Tor (hybrid) which carry tcpA classical genes or classical $c t x \mathrm{~A}$ or $c t x \mathrm{~B}$ genes have been reported from clinical cases of cholera from Bangladesh (Safa et al., 2006). The nontoxigenic strains of $\mathrm{O} 1$ are different in terms of its biochemical and serological properties. Clinical and environmental origin of nontoxigenic strains of $\mathrm{O} 1$ has been reported from several countries (Faruque et al., 1998; Wang et al., 2020). However, the non-toxigenic strains lacking toxigenic genes also have the potential of causing diarrhoea in human (Azarian et al., 2016). The mechanism of virulence and pathogenicity of this strain remains unknown. Joseph et al. (2015) reported the cause of infection in moribund shrimps, $P$. monodon, from a cultured farm is due to $V$. cholerae $\mathrm{O} 139$ strain, capable of infecting human via contact. Azarian et al. (2016) have identified two environmental non-toxigenic $V$. cholerae $\mathrm{O} 1$ strains lacking $c t x$ gene. However, these strains possess classical tcpA genes. Genetic analysis revealed that these strains are phylogenetically comparable with clinical and environmental strains of O1, O139 and nonO1 V. cholerae strains. Saravanan et al. (2007) reported the presence of $V$. cholerae $\mathrm{O} 139$ in shrimp from local fish market in southern India. The detection of choleragenic V.cholerae $\mathrm{O} 1$ Ogawa, El Tor strains in shrimp and fish samples from Cochin by Kumar and Lalitha (2013) suggested that the seafood pose a serious risk to the consumers.

Listeria monocytogenes: Listeria monocytogenes is major concern in lightly preserved 
food products and the prevalence of this bacterium is considerably increased in ready to eat fishery products (Jami et al., 2014). Seafood has the highest risk among the minimally processed products (Rocourt et al., 2003). L. monocytogenes enters into seafood by cross-contamination and the presence of this pathogen in seafood has been reported from different seafood products (Jami et al., 2014; Basha et al., 2019). Prevalence rate of this pathogen in seafood products varies from 0 to 17\% (Fallah et al., 2013; Momtaz and Yadollahi, 2013). However, the prevalence in seafood is relatively low compared to other food products such as dairy and other animal products (Basha et al., 2019). The mortality rate due to $L$. monocytogenes infection is very high ranging from $20 \%$ to $30 \%$ in immunocompromised patients and hence an important public health concern. The symptoms of infection include septicemia, meningitis, gastroenteritis, pneumonia and spontaneous abortion (Vazquez-Boland et al., 2001). Regulatory agencies such as Food and Drug Administration (FDA), International Standard Organization (ISO), World Health Organization (WHO) etc. have included this pathogen in zero tolerant categories in processed food products due to its survivability in wide environmental conditions (O'Connor et al., 2010). This pathogen is able to withstand high $\mathrm{NaCl}$ concentration of upto $20 \%, \mathrm{pH}$ range of 4.1 to 9.8 , temperature range of 0.5 to $45^{\circ} \mathrm{C}$ and low water activity of 0.91 (Lungu et al., 2009). This pathogen is very well adapted to grow in refrigerated condition and pose serious risk to the chilled and frozen products once it is contaminated. There has been an increase in the incidence of this pathogen in Indian seafood especially from Mangalore, Mysore and Goa region since 1992 (Norhana et al., 2010). The prevalence of this pathogen in fresh and processed fishery products from Cochin region ranged from 1.2 to 2.7\% (Das et al., 2013; Basha et al., 2019). Moharem et al. (2007) reported an incidence of $1.83 \%$ from fresh fish samples. Incidence of L. monocytogenes was reported in seafood from fish markets of Goa (Parihar et al., 2008; Gawade et al., 2010). CDC (2011) have reported that raw, smoked, cooked, lightly processed products of fish, meat and milk are more likely to be contaminated by this pathogen, causing serious health issues to people who consumed it.

Yersinia spp.: The genus Yersinia belongs to Enterobacteriaceae family. Presently, it comprises of 16 species and two species ( $Y$. enterocolitica and $Y$. pseudotuberculosis) are pathogenic to human (Simonova et al., 2007). $Y$. enterocolitica is widely distributed in aquatic and animal reservoirs with swine serving as a major reservoir. Yersiniosis is caused by $Y$. enterocolitica of which virulence biotypes associated with infections are biotypes $1 \mathrm{~B}, 2,3,4$, and 5 . The spectrum of disease ranges from mild diarrhoea to acute gastroenteritis, enterocolitis and pseudo appendicitis in humans (Bottone, 1997). $Y$. enterocolitica is able to withstand freezing for long period of time and remain viable after extended frozen storage which raises public health concerns in the low temperature preservation and processing of seafood. A study of various water sources in Brazil confirmed the presence of pathogenic strains of $Y$. enterocolitica belonging to virulence biotype 2 and 3 (Falcão et al., 2004). Cheyne et al. (2009) found that the Yersinia spp. recovered from water sources were nonpathogenic in nature. Sinha et al. (2000) reported non-pathogenic biotypes of $Y$. enterocolitica from Indian waters. However, there was no correlation between the presence of faecal pollution and occurrence of Yersinia spp. in water. The prevalence of Yersinia species in Indian seafood samples were reported by Kishore et al. (2012) with 54\% of Y. intermedia, $19 \%$ Y. aldovae and low prevalence $(0.03 \%)$ of Y. enterocolitica. Later Akhila et al. (2013) and Shanmugapriya et al. (2014) have reported the prevalence of $20 \%$ and $75 \%$ of $Y$. enterocolitica in fish samples.

Clostridium botulinum: C. botulinum is grouped under Gram positive bacteria, and is 
anaerobic spore producing bacilli of important public health concern in seafood industry (Lalitha and Gopakumar, 2000). This bacterium is autochthonous to the aquatic environment and aquatic sediments forms major reservoir of this pathogen. The toxigenic types of Clostridium botulinum belong to type A, B, E and $\mathrm{F}$ (Lindstrom et al., 2001). The major risk factors in seafood are due to the presence of these toxigenic types. Botulinum food poisoning is due to the consumption of food contaminated with preformed toxins of C. botulinum and low oral dose of $70 \mu \mathrm{g}$ is sufficient to causes illness in human (GonzálezEscalona et al., 2014). Its prevalence in seafood depends upon several factors such as topographical location, culture practices, detection methods etc. The fish poses serious risk due to its direct contact with sediment and the ingestion of spores through contaminated feed/sediment. This bacterium is a major concern in packaged seafood products where cold chain is not maintained during storage, transport and distribution chain. The favourable condition for the growth of $C$. botulinum in preserved products such as in modified atmospheric packaging or vacuum-packed products include, $\mathrm{pH}$ of about 4.6, water activity of $0.93 \%$, low salt upto $3 \%$, temperature range of $3^{\circ} \mathrm{C}$ to $50^{\circ} \mathrm{C}$ (Genigeorgis, 1985). It is reported that the non-pathogenic types belonging to type $\mathrm{C}$ and $\mathrm{D}$ are more prevalent in sea foods from India (Lalitha and Gopakumar, 2000). C. botulinum was detected in fresh and salted fish sold in retail markets in Cochin, Kerala (Lalitha and Surendran, 2002). It was found that, $C$. botulinum types A-E were able to grow and produce toxin at $15^{\circ} \mathrm{C}$ and $30^{\circ} \mathrm{C}$ stored in modified atmospheric seafood products (Lalitha and Gopakumar, 2001). The fatality rate is reported to be high as compared to other foodborne pathogens (Shukla and Sharma, 2005). It was reported that about $C$. botulinum contributes $0.2 \%$ of the total food outbreaks in different states of the European Union in 2017 with $7.7 \%$ mortality cases (EFSA / ECDC, 2019).

Bacillus cereus: Bacillus cereus is spore forming, Gram positive, motile bacteria and is widely distributed in the environment (Das et al., 2009). Even though this bacterium is autochthonous to the natural environment including aquatic environment, it is considered as human pathogenic bacteria due to its ability to produce heat resistant endospores, which can withstand extreme environmental conditions and capable of producing toxins in wide variety of foods (Ankolekar, 2009). The minimum level of $10^{3} \mathrm{CFU} / \mathrm{g}$ B. cereus in food is sufficient to produce toxin (Ankolekar, 2009). It produces heat, acid resistant emetic toxin called celuride, which causes emetic illness. Based on the production of enterotoxin, $B$. cereus is classified as haemolytic $B$. cereus (HBL) encoded by enterotoxin genes such as $h b l A, h b l C, h b l D$ and non-haemolytic $B$. cereus (NHE) encoded by nheA, nheB, nhe $C$. These enterotoxins are responsible for diarrhoeal illness in human. The other enterotoxins reported in food poisoning are Ent FM, Cytotxin K (Schmid et al., 2021). The non-seasonal occurrence of $B$. cereus food poisoning has been reported Tewari et al., 2015). In Europe, the first report of Bacillus food poisoning was from vanilla sauce which caused diarrhoeal type illness in 61 persons (Mortimer and McCann, 1974). Rahmati and Labbe (2008) reported $48 \%$ haemolytic $B$. cereus in fresh and processed seafood samples from USA. Gdoura-Ben Amor et al. (2018) reported B. cereus in $32.3 \%$ of seafood. In India, incidence rate of $36.2-40 \%$ were reported in seafood (Kamat et al., 1989; Das et al., 2009). The first outbreak of seafood associated B. cereus food poisoning from Calvia (Spain) where the insufficient cooking of ready to eat tuna steaks was reported in emetic illness (Doménech-Sánchez et al., 2011). Recently, Schmid et al. (2021) confirmed the presence of $B$. cereus strains in fibre-based packaging materials that shares same phylogenetic characteristics of the strains found in food and environment.

Shigella spp.: Shigella spp. belongs to Enterobacteriaceae family causes shigellosis in humans. This bacterium is recognized as a major public health threat in most of the 
developing countries (Nadella et al., 2019). The main symptoms include watery diarrhoea, fever and abdominal pain. The pathogenic species identified are S. dysenteriae, S. flexineri, S. boydii and S. sonnei (Niyogi, 2005). Fatality rate is more in children of age less than five years (Nadella et al., 2019). The main route of infection is through contaminated water and foods (Sujatha et al., 2011). A low dose of even 10 numbers of bacteria can sufficient to multiply inside the intestinal mucosa and cause dysentery (Nadella et al., 2019). The main virulence factors described in Shigella spp. are ial (invasion associated locus) and ipa $B C D$ (invasion plasmid antigen) (Malau et al., 2018). The occurrences of Shigella spp. in seafood have been reported in India using conventional plating techniques (Sujatha et al., 2011; Obaidat and Salman, 2017). Improved method using enrichment PCR along with traditional methods may be opted for the better recovery of these bacteria in seafood with a view of improving its detectability in the presence of other background flora (Nadella et al., 2019).

\section{Emerging pathogens in seafoods}

Apart from the well reported sea food borne pathogens, several other pathogens are also emerging throughout the world irrespective of the geographical conditions that are able to cause infectious diseases. It is not always true that emerging pathogens are a new category of microorganisms instead, it can be an already established pathogen in which the virulence or disease characteristics is high as a result of stressful conditions such as changes in the habitat, climate, overdose of antibiotics etc. It is important to study the time of emergence of particular bacteria of infectious category to the food chain via source tracking and establishment of national network of surveillance system, so that the epidemic spread can be controlled by effective implementation of the mitigation measures and re-emergence can be prevented. The pathogens of emerging category in seafood include Vibrio vulnificus, Vibrio mimicus, Cronobacter, Campylobacter spp., Arcobacter spp. etc. The occurrence of these pathogens in disease outbreaks in human have been reported from all over the world.

Vibrio vulnificus: Vibrio vulnificus is a halophilic bacterium belonging to Vibrionaceae and widely distributed in brackish water and marine environments. High concentration of these bacteria can be seen in filter feeding bivalves that inhabits coastal polluted waters. So, the major risk factor for the foodborne outbreak is the consumption of contaminated raw or partially cooked shellfish (Karunasagar and Rohit, 2012). Infection can also occur through open wounds and may lead to septicaemia in fatal cases. The fatality rate of $V$. vulnificus infection ranges from 20 to $60 \%$ (CDC, 2014; Pei et al., 2017). Recently, this bacterium has emerged as significant public health bacteria due to its high fatality rate all over the world (Pei et al., 2017). This bacterium is considered as a most fatal foodborne pathogen in USA (Pei et al., 2017). Out of the three biotypes known, biotype 1 is responsible for human infections (Thiaville et al., 2011). The major virulence factors in $V$. vulnificus are RtxAl, haemolysin $(V v h A)$ and metalloprotease like $V v p E$ and $V v p M$ gene which are responsible for haemolytic, cytotoxic and iron acquisition activities (Lee et al., 2014). Wide variety of seafoods have been implicated in $V$. vulnificus contamination (Karunasagar and Rohit, 2012; Phillips and Satchell, 2017). The prevalence of this bacteria in seafood were 3.5 to $8 \%$ in Europe, $2.4 \%$ in South East Asia, 75 to $80 \%$ in oysters from India, $100 \%$ oysters from USA (Jones et al., 2014). The incidence of this pathogen in fish samples from India is about $16.6 \%$ (Thampuran and Surendran, 1998). However, incidence of this pathogen in oyster is high (Karunasagar and Rohit, 2012). Seafoodborne outbreaks were mostly reported from South American countries such as Peru (Ibarra et al., 1999), Chile (Poblete et al., 2002), Equador (Villacrés et al., 2013) Brazil (Costa et al., 2013; Franca et al., 2013). In India, $V$. vulnificus infection was reported in a case 
of gastroenteritis with septicaemia in a child, who had a prior history of contact with seawater (Saraswathi et al., 1989). Madiyal et al. (2016) reported rare cause of necrotising fasciitis in person who had a history of exposure to sea water due to $V$. vulnificus infection. Later, Bhat et al. (2019) reported necrotising fasciitis from India where contaminated seawater is most probable cause of infection. Recently, two cases of seafood related $V$. vulnificus infection were confirmed by PCR targeting virulence genes $r t x A$, vvhaA from Mangalore, India (D'Souza et al., 2018).

Campylobacter spp.: Campylobacter spp. causes gastrointestinal disease termed campylobacteriosis and one of the leading causes of foodborne outbreaks in developed countries. Since 2005 to 2019, this bacterium has been implicated in gastrointestinal disease of more than 2,20,000 people in EU and ranks first in foodborne outbreak followed by Salmonella and Yersinia (EFSA, 2010). USA alone reports 8.45 lakh cases of Campylobacter infection per year (CDC, 2011). The outbreak is mainly due to ingestion of contaminated food products, where the chicken alone contributes to about $25 \%$ of the infections (Wingstrand et al., 2006). The incidence of Campylobacter spp. has been reported in other types of food animals such as cattle, pig, cows, sheep etc (Stanley and Jones, 2003). The Campylobacter spp. is a commensal bacterium to poultry and the intestinal tract carry huge amount of these bacteria. The rupture of intestinal tract while processing can disseminate the content to skin. Cross contamination with shellfish harvesting area and handlers can result in seafoodborne outbreak. Human campylobacteriosis are mainly due to $C$. jejuni and it causes 12 times more cases than $C$. coli in England (Friedman et al., 2000). Shellfish associated campylobacteriosis was first reported during 1980s where 28 persons were infected after eating raw clams (Griffin et al., 1983). After this, few shell fish outbreaks were reported (Abeyta et al., 1993; Wilson and Morre, 1996) and the occurrence of this bacterium in sea waters are frequently reported in recent years (Wilkes et al., 2011). After a long period of absence, this enteric pathogen was again isolated from shellfish from France by Rincee et al. (2018) with a lower prevalence rate of $27.8 \%$ in contrast to the prevalence rate of $42 \%$ reported by Wilson and Morre (1996). The evidence of this pathogen in shellfish and shell fish harvested area points to the need to include this bacterium in general microbiological monitoring programme.

Cronobacter spp.: Cronobacter species belongs to the family Enterobacteriaceae and is considered as an opportunistic pathogen in neonates (Das et al., 2021). Among 7 species of Cronobacter, three species are pathogenic to human, namely $C$. sakazakii, $C$. malonaticus and $C$. turicensis. Out of these, C. sakazakii causes high mortality rate of about $40-80 \%$ in neonates (Miranda et al., 2017). This bacterium has been isolated from wide range of food sources such as dairy products, plant-based products, dried fish, shrimp, seaweeds and minimally proceeds products (Singh et al., 2015; Das et al., 2021). This bacterium is considered as an emerging pathogen of seafood recently due to its survivability in low moisture foods such dried fish product (Das et al., 2021). However, the seafoodborne outbreak due to this bacterium has not been reported so far. Recently, incidence study of Cronobacter in different food products from 44 countries by Miranda et al. (2017) reported an isolation rate of $9.1 \%$ in seafood. The presence of Cronobacter spp. in Indian seafoods was first reported from Mumbai, where the highest incidence was in dried and dehydrated fish (55.6\%); followed by shellfishes (33.3\%), fresh fish (6.3\%) (Das et al., 2021). The pathogenicity of this bacterium is due to the presence outer membrane protein A (ompA), plasminogen activator ( (hly) gene (Singh et al., 2015). These putative virulence factors were widely distributed in plant-based products and clinical samples. The 
omp A gene is thought to be present in all Cronobacter species and this gene is also present in invasive $E$. coli causing neonatal meningitis (Kim et al., 2000). However, the presence of cpa and hly genes are not reported in seafood products which suggest the presence of specific genetic factors in seafood associated Cronobacter spp. (Das et al., 2021).

Arcobacter spp.: Arcobacter is an emerging zoonotic pathogen, belongs to Campylobacteraceae and is closely related to the Genus Campylobacter (Zhang et al., 2019). They are able to survive in low oxygen condition, and well adapted to temperature of less than $30^{\circ} \mathrm{C}$ (Ramees et al., 2017). Arcobacter causes bacteraemia, gastroenteritis and diarrhoea (Collado and Figueras, 2011). Out of 27 species identified, only three species are pathogenic causing disease; A. butzleri, A. cryaerophilus and A. skirrowii. Foodborne infection associated with chicken and vegetables have been reported (González and Ferrus, 2011; Ramees et al., 2017). Seafoodborne outbreak due to Arcobacter has not been reported so far; however reports of isolation of Arcobacter from fish, shellfish, and seawater are available (Romero et al., 2002; Laishram et al., 2016; Zhang et al., 2019). The genus Arcobacter was first recognized during 1991 and the main reservoir identified was poultry (Ramees et al., 2017). Since 2005, many of the new species have been first identified from shell fishes, mussels, and seawater. The first report of Arcobacter mytili and $A$. molluscorum were from mussels (Figueras et al., 2011) and A. bivalviorum, A. venerupis and $A$. venerupis from shellfishes (Levican et al., 2012; Levican et al., 2013). The high prevalence and emergence of new species in shellfishes were attributed to the presence of faecal pollution in shellfish growing areas.

This bacterium has been frequently isolated from different animal sources such as cattle, pig, plants, humans etc. (Ramees et al., 2017). The transmission route for Arcobacter infection is polluted water and food sources. Fisher et al. (2014) reported that Arcobacter contributes $5-11 \%$ of the bacterial population in sewage. Consumption of contaminated products such as raw or partially cooked chicken meat, pork and seafoods are main sources of infections in humans (Collado et al., 2009). The pathogenicity of Arcobacter to human is unclear till now. The epidemiological surveillance studies and source tracking are essential to know the disease burden of Arcobacter contaminated food including seafood.

Vibrio mimicus: Vibrio mimicus is an important emerging zoonotic pathogen in seafood that causes disease in aquaculture fishes as well as gastroenteritis in human (Nilavan et al., 2021). Major reservoirs of this pathogen are raw oysters, fish, turtle eggs, shrimps, cray fish etc. Davis et al. (1981) while studying the biochemical characteristics of atypical $V$. cholerae by biochemical tests revealed a new species that was sucrose negative for which the name Vibrio mimicus sp. nov. was proposed. $V$. mimicus carrying ctx gene is reported as pathogenic strain that can cause severe watery diarrhoea and gastrointestinal disorders (Nair et al., 2012). An asymptomatic infection of V. cholerae $/ V$. mimicus was reported in $52.6 \%$ of fecal microbiota of healthy children in an urban slum in Kolkata stating a risk of spreading the contamination among the population (Nair et al., 2012). In India, there were only few reports of this organism from seafoods. In a prevalence study of pathogenic Vibrios from shellfish of Cochin market, Sudha et al. (2014) reported $1 \% \mathrm{~V}$. mimicus among potentially pathogenic Vibrio species. Recently, Nilavan et al. (2021) reported a prevalence of $5.6 \%$ in seafood with maximum prevalence in fresh water (18\%) and brackish water (19\%) fish samples compared to marine fish samples $(2 \%)$. $V$. mimicus haemolysin gene was present in $12 \%$ of the raw and RTE seafood in northwest Mexico indicating potential risk to consumers (Guardiola-Avila et al., 2015). The consumption of raw or partially cooked fish pose major risk in seafood related outbreak by this 
bacterium. Further there is urgent need for implementation of effective preventive measures in the food supply and value chain.

\section{Conclusion}

In recent years, the increased use of fresh, iced and processed seafood demands improved surveillance on seafood microbiological quality to control the foodborne pathogens. Modern facilities in fish markets offer good quality seafood for domestic consumption. The thumb rule in maintaining safety in seafood includes time and temperature control, hygiene and cleanliness of the workers, production area, utensils and avoidance of cross contamination. Increased awareness programme and effective governance and management strategies for assuring the quality of seafood is the need of the hour.

Food safety with respect to seafood pathogens is important in terms of public health perspective as over 200 types of diseases are due to the consumption of contaminated foods (WHO, 2015). Control of pathogens in fishery products can be achieved by following either or the combination of preservation techniques such as storing the products at low temperature preferably at chilled/frozen condition, use of heat treatment etc. One of the food safety concerns of Vibrios is the ability of viable but non culturable (VBNC) state of Vibrio species

\section{REFERENCES}

Abeyta C, Deeter FG, Kaysner CA, Stott RF and Wekell MM, 1993. Campylobacter jejuni in a Washington state shellfish growing bed associated with illness. J Food Prot, 56(4): 323325, doi: 10.4315/0362-028X-56.4.323

Akhila S, Shanmuga S, Senthil T and Thayumanavan T, 2013. Molecular diversity analysis of Yersinia enterocolitica isolated from marine marketed fish. Int J Curr Microbiol App Sci, 2: 204-214

Albert MJ, 1994. Vibrio cholerae O139 Bengal. J Clin Microbiol, 32(10): 2345-2349

Amagliani G, Brandi G and Schiavano GF, 2012. Incidence and role of Salmonella in seafood safety. Food Res Int, 45(2): 780-788, doi: 10.1016/j.foodres.2011.06.022

Angelillo IF, Viggiani NM, Rizzo L and Bianco A, 2000. which is very difficult to detect in food by routine microbiological tests. To ensure food safety, routine microbiological screening tests should be validated in real time so that the contaminated food product gets detected. National regulations shall be enforced for ensuring food safety that includes the strict implementation of food hygiene and sanitation programme through Hazard analysis and critical control point (HACCP), together with Good management practices (GMP), Standard operating procedures (SOPs), Sanitation standard operating procedures (SSOPs) practices from production to consumption stages, there by the product becomes safe at all stages of production, processing and distribution levels. The harmonization of these practices in international trade ensures the safety of seafood products, globally.

Conflict of interest: Authors have no conflict of interest in this study.

Author's contribution: TCJ: Conception and design of the work, critical revision of the article; MVA: Data collection, analysis and interpretation, drafting the article.

\section{ACKNOWLEDGEMENT}

The authors express their sincere gratitude to the Director, ICAR-Central Institute of Fisheries Technology, Cochin.

Food handlers and foodborne diseases: knowledge, attitudes, and reported behavior in Italy. J Food Prot, 63(3): 381-385, doi: 10.4315/0362-028X-63.3.381

Anjay, Das SC, Kumar A, Kaushik P and Kurmi B, 2014. Occurrence of Vibrio parahaemolyticus in marine fish and shellfish. IJMS, 43(5): 887-890

Anjay, Das SC, Kumar A, Kaushik P and Kumari S, 2016. Pathogenic and pandemic Vibrio parahaemolyticus detection in fish and shellfish isolates. IJMS, 45(9): 1195-1198

Ankolekar CR, 2009. Levels, enterotoxigenicity, growth and physical characteristics of B. Cereus from US retail rice. Masters Theses, University of Massachusetts Amherst, pp 262

Antony B, Dias M, Shetty AK and Rekha B, 2009. Food poisoning due to Salmonella enterica 
serotype Weltevreden in Mangalore. Ind J Med Microbiol, 27(3): 257-258, doi: 10.4103/ 0255-0857.53211

Antony AC, Silvester R, Divya PS, Aneesa PA, Francis $\mathrm{B}$ et al., 2021. Faecal contamination and prevalence of pathogenic $E$. coli in shellfish growing areas along South-West coast of India. Reg Stud Mar Sci, 44: 101774, doi: 10.1016/j.rsma.2021.101774

Ayyappan MV, Balange AK, Nayak BB and Kumar S, 2018. Distribution of potentially pathogenic Vibrio parahaemolyticus in seafood and the aquatic environment of Mumbai, India. Fishery Tech, 55(3): 205-211

Azarian T, Ali A, Johnson JA, Jubair M, Cella E et al., 2016. Non-toxigenic environmental Vibrio cholerae $\mathrm{O} 1$ strain from Haiti provides evidence of pre-pandemic cholera in Hispaniola. Sci Rep, 6(1): 36115, doi: 10.1038/srep36115

Barlow RS, Hirst RG, Norton RE, Ashhurst-Smith C and Bettelheim KA, 1999. A novel serotype of enteropathogenic Escherichia coli (EPEC) as a major pathogen in an outbreak of infantile diarrhoea. J Med Microbiol, 48(12): 1123-1125, doi: 10.1099/00222615-48-12-1123

Barret KA, Nakao JH, Taylor EV, Eggers C and Gould LH, 2017. Fish associated foodborne disease outbreaks: United States, 1998-2015. Foodborne Pathog Dis, 14: 537-543, doi: 10.1089/ fpd.2017.2286

Basha KA, Kumar NR, Das V, Reshmi K, Rao BM et al., 2019. Prevalence, molecular characterization, genetic heterogeneity and antimicrobial resistance of Listeria monocytogenes associated with fish and fishery environment in Kerala, India. Lett Appl Microbiol, 69(4): 286-293, doi: 10.1111/lam.13205

Beatty ME, Adcock PM, Smith SW, Quinlan K, Kamimoto LA et al., 2006. Epidemic diarrhea due to enterotoxigenic Escherichia coli. Clin Infect Dis, 42(3): 329-334, doi: 10.1086/499246

Beuchat LR, 1982. Vibrio parahaemolyticus: public health significance. Food Technol, 36(3): 80-83

Bhat P, Bhaskar M, Sistla S and Kadhiravan T, 2019. Fatal case of necrotising fasciitis due to Vibrio vulnificus in a patient with alcoholic liver disease and diabetes mellitus. BMJ Case Rep, 12(1): bcr2018-227851, doi: 10.1136/bcr-2018-227851

Bisht A, Kamble MP, Choudhary P, Chaturvedi K, Kohli G et al., 2021. A surveillance of food borne disease outbreaks in India: 2009-2018. Food Cont, 121: 107630, doi: 10.1016/ j.foodcont.2020.107630
Bottone EJ, 1997. Yersinia enterocolitica: The charisma continues. Clin Microbiol Rev, 10: 257276, doi: 10.1128/CMR.10.2.257

Boziaris IS and Parlapani FF, 2017. Specific spoilage organisms (SSOs) in fish. Microbiol Quality food, 61-98, doi: 10.1016/B978-0-08-100502-6.00006-6

Brands DA, Inman AE, Gerba CP, Maré CJ, Billington SJ et al., 2005. Prevalence of Salmonella spp. in oysters in the United States. Appl Environ Microbiol, 71(2): 893-897, doi: 10.1128/AEM.71.2.893-897.2005

Bukola D and Zaid A, 2015. Consequences of anthropogenic activities on fish and the aquatic environment. Poultry Fish Wildl Sci, 3(02): 138150 doi: 10.4172/2375-446X.1000138

Callejon RM, Rodríguez-Naranjo MI, Ubeda C, Hornedo-Ortega R, Garcia-Parrilla MC et al., 2015. Reported foodborne outbreaks due to fresh produce in the United States and European Union: trends and causes. Foodborne Pathog Dis, 12(1): 32-38, doi: 10.1089/fpd.2014.1821

Canizalez-Roman A, Gonzalez-Nuñez E, Vidal JE, Flores-Villaseñor H and León-Sicairos N, 2013. Prevalence and antibiotic resistance profiles of diarrheagenic Escherichia coli strains isolated from food items in North Western Mexico. Int J Food Microbiol, 164(1): 36-45, doi: 10.1016/j.ijfoodmicro.2013.03.020

Carnicer-Pont D, Bailey KA, Mason BW, Walker AM, Evans MR et al., 2006. Risk factors for hospitalacquired methicillin-resistant Staphylococcus aureus bacteraemia: A case-control study. Epidemiol Infect, 134(6): 1167-1173, doi: $10.1017 / \mathrm{S} 0950268806006327$

CDC, 2011. Multistate outbreak of listeriosis associated with Jensen farms cantaloupe-United States, August-September 2011. Morb Mortal Wkly Rep, 60(39): 1357-1358

CDC (Centers for Disease Control and Prevention), 2014. National surveillance of bacterial foodborne illnesses (Enteric Disease). Available in http://www.cdc.gov/nationalsurveillance/ cholera-vibrio-surveillance.html [25 June, 2014]

Cheyne BM, Van Dyke MI, Anderson WB and Huck PM, 2009. An evaluation of methods for the isolation of Yersinia enterocolitica from surface waters in the Grand River watershed. J Water Health, 7(3): 392-403, doi: 10.2166/wh.2009.084

Chua TE, Paw JN and Guarin FY, 1989. The environmental impact of aquaculture and the effects of pollution on coastal aquaculture development in Southeast Asia. Mar Pollut Bull, 
20(7): 335-343 doi: 10.1016/0025326X(89)90157-4

Collado L and Figueras MJ, 2011. Taxonomy, epidemiology, and clinical relevance of the genus Arcobacter. Clin Microbiol Rev, 24(1): 174-192, doi: 10.1128/CMR.00034-10

Collado L, Guarro J and Figueras MJ, 2009. Prevalence of Arcobacter in meat and shellfish. J Food Protect, 72(5): 1102-1106, doi: 10.4315/0362028X-72.5.1102

Costa RA, Araújo RL and Vieira RHSDF, 2013. Hemolytic and urease activities in Vibrios isolated from fresh and frozen oysters. Rev Soc Bras Med Trop, 46: 103-105, doi: 10.1590/0037868210722013

D'Souza C, Kumar BK, Kapinakadu S, Shetty R, Karunasagar I et al., 2018. PCR-based evidence showing the presence of Vibrio vulnificus in wound infection cases in Mangaluru, India. Int $\mathbf{J}$ Infect Dis, 68: 74-76, doi: 10.1016/ j.ijid.2018.01.018

Das S, Lalitha KV, Thampuran N and Surendran PK, 2013. Isolation and characterization of Listeria monocytogenes from tropical seafood of Kerala, India. Ann Microbiol, 63(3): 1093-1098, doi: 10.1007/s13213-012-0566-9

Das S, Surendran PK and Thampuran N, 2009. PCRbased detection of enterotoxigenic isolates of Bacillus cereus from tropical seafood. Ind J Med Res, 129: 316-320

Das SK, Kumar SH, Nayak BB and Lekshmi M, 2021. Isolation and identification of Cronobacter spp. from fish and shellfish sold in retail markets. Curr Microbiol, 78(5): 1973-1980, doi: 10.1007/ s00284-021-02447-3

Daskalov H, 2006. The importance of Aeromonas hydrophila in food safety. Food control, 17(6): 474-483, doi: 10.1016/j.foodcont.2005.02.009

Davis BR, Fanning GR, Madden JM, Steigerwalt AG, Bradford Jr HB et al., 1981. Characterization of biochemically atypical Vibrio cholerae strains and designation of a new pathogenic species, Vibrio mimicus. J clin Microbiol, 14(6): 631-639, doi: $10.1128 / \mathrm{jcm} .14 .6 .631-639.1981$

Decludt B, Bouvet P, Mariani-Kurkdjian P, Grimont F, Grimont PAD et al., 2000. Haemolytic uraemic syndrome and Shiga toxin-producing Escherichia coli infection in children in France. Epidemiol Infect, 124(2): 215-220, doi: 10.1017/ S0950268899003623

DePaola A, Jones JL, Woods J, Burkhardt III W, Calci KR et al., 2010. Bacterial and viral pathogens in live oysters: 2007 United States market survey. Appl Environ Microbiol, 76(9): 27542768, doi: 10.1128/AEM.02590-09

Dewey-Mattia D, Manikonda K, Hall AJ, Wise ME and Crowe SJ, 2018. Surveillance for foodborne disease outbreaks-United States, 20092015. MMWR Surveill Summ, 67(10): 1-11, doi: 10.15585/mmwr.ss6710a1

Divya SP and Hatha AM, 2019. Screening of tropical estuarine water in south-west coast of India reveals emergence of ARGs-harboring hypervirulent Escherichia coli of global significance. Int J Hyg Environ Health, 222(2): 235-248, doi: 10.1016/j.ijheh.2018.11.002

Doménech-Sánchez A, Laso E, Pérez MJ and Berrocal CI, 2011. Emetic disease caused by Bacillus cereus after consumption of tuna fish in a beach club. Foodborne Pathog Dis, 8(7): 835-837, doi: 10.1089/fpd.2010.0783

Dumen E, Ekici G, Ergin S and Bayrakal GM, 2020. Presence of foodborne pathogens in seafood and risk ranking for pathogens. Foodborne Pathog Dis, 17(9): 541-546, doi: 10.1089/fpd.2019.2753

EFSA and ECDC, 2019. The European Union one health 2018 zoonoses report. EFSA J, 17(12): e05926, doi: $10.2903 /$ j.efsa.2019.5926

EFSA, 2010. The community summary report on trends and sources of zoonoses, zoonotic agents and foodborne outbreaks in the European Union in 2008. EFSA J, 8: 1496-1906, doi: 10.2903/j.efsa.2010.1496

Falcão JP, Brocchi M, Proenca-Modena JL, Acrani GO, Correa EF et al., 2004. Virulence characteristics and epidemiology of Yersinia enterocolitica and Yersiniae other than Y. pseudotuberculosis and $Y$. pestis isolated from water and sewage. J Appl Microbiol, 96(6): 1230-1236, doi: 10.1111/ j.1365-2672.2004.02268.x

Fallah AA, Saei-Dehkordi SS and Mahzounieh M, 2013. Occurrence and antibiotic resistance profiles of Listeria monocytogenes isolated from seafood products and market and processing environments in Iran. Food control, 34(2): 630636, doi: 10.1016/j.foodcont.2013.06.015

FAO, 2018. The State of World Fisheries and Aquaculture 2018 - Meeting the sustainable development goals. Rome, pp 224, Licence: CC BY-NC-SA 3.0 IGO

FAO, 2020. The State of World Fisheries and Aquaculture 2020 - UN Food and Agriculture Organization (FAO). http://www.fao.org/state-offisheries-aquaculture/ en

Faruque SM, Balakrish Nair G and Mekalanos JJ, 2004. 
Genetics of stress adaptation and virulence in toxigenic Vibrio cholerae. DNA Cell Biol, 23(11): 723-741, doi: 10.1089/ dna.2004.23.723

Faruque SM, Asadulghani, Saha MN, Alim AA, Alber MJ et al., 1998. Analysis of clinical and environmental strains of nontoxigenic Vibrio cholerae for susceptibility to СТХФ: molecular basis for origination of new strains with epidemic potential. Infect Immun, 66(12): 5819-5825, doi: 10.1128/IAI.66.12.5819-5825.1998

Feldhusen F, 2000. The role of seafood in bacterial foodborne diseases. Microb Infect, 2(13): 16511660, doi: 10.1016/S1286-4579(00)01321-6

Fernandez L, Lopez JR, Secades P, Menendez A, Marquez I et al., 2003. In vitro and in vivo studies of the Yrpl protease from Yersinia ruckeri and its role in protective immunity against enteric red mouth disease of salmonids. Appl Environ Microbiol, 69(12): 7328-7335, doi: 10.1128/ AEM.69.12.7328-7335.2003

Figueras MJ, Levican A, Collado L, Inza MI and Yustes C, 2011. Arcobacterellisii sp. nov., isolated from mussels. Syst Appl Microbiol, 34(6): 414-418, doi: 10.1016/j.syapm.2011.04.004

Fisher JC, Levican A, Figueras MJ and McLellan SL, 2014. Population dynamics and ecology of Arcobacter in sewage. Front Microbiol, 5: 525, doi: 10.3389/fmicb.2014.00525

Franca JCB, Sanfelice E, Gentili A, Raboni SM, Polido $\mathrm{D}$ et al., 2013. Vibrio vulnificus infection in Southern Brazil-case report. An Bras Dermatol, 88(3): 424-426, doi: 10.1590/abd18064841.20131780

Friedman CR, Neimann J, Wegener HC and Tauxe RV 2000. Epidemiology of Campylobacter jejuni infection in the United States and other industrialized nations. In: Campylobacter (2nd edition (Nachamkin MJ, Blaser, (Eds). ASM Press, Washington, DC, pp 121-138

Fujino T, Okuno Y, Nakada D, Aoyama A, Fukai Ket al., 1953. On the bacteriological examination of Shirasufood poisoning. Med J Osaka Univ, 4: 299-304

Gawade L, Barbuddhe SB and Bhosle S, 2010. Isolation and confirmation of Listeria species from seafood off Goa region by polymerase chain reaction. Indian J Mcrobiol, 50(4): 385-389, doi: 10.1007/s12088-011-0064-y

Gbadegesin O and Akintola S, 2021. Charting the course for a blue economy in Nigeria: A Legal Agenda. Opeyemi, 1: 6-25

Gdoura-Ben Amor M, Siala M, Zayani M, Grosset N,
Smaoui S et al., 2018. Isolation, identification, prevalence, and genetic diversity of Bacillus cereus group bacteria from different foodstuffs in Tunisia. Front Microbiol, 9: 447, doi: 10.3389/ fmicb.2018.00447

Geetha R, Ravisankar T, Patil PK, Avunje S, Vinoth S et al., 2020. Trends, causes, and indices of import rejections in international shrimp trade with special reference to India: A 15-year longitudinal analysis. Aquacu Int, 28(3): 1341-1369, doi: 10.1007/s10499-020-00529-w

Genigeorgis CA, 1985. Microbial and safety implications of the use of modified atmospheres to extend the storage life of fresh meat and fish. Int J Food Microbiol, 1(5): 237-251, doi: 10.1016/ 0168-1605(85)90016-9

Giusti MD, Medici DD, Tufi D, Carolina M and Boccia A, 2007. Epidemiology of emerging foodborne pathogens. Epidemiol Emerg foodborne Pathog, 4(1): 24-31 doi: 10.2427/5898

González A and Ferrús MA, 2011. Study of Arcobacter spp. contamination in fresh lettuces detected by different cultural and molecular methods. Int J Food Microbiol, 145(1): 311-314, doi: 10.1016/ j.ijfoodmicro.2010.11.018

Gonzalez-Escalona N, Thirunavukkarasu N, Singh A, Toro M, Brown EW et al., 2014. Draft genome sequence of bivalent Clostridium botulinum strain IBCA10-7060, encoding botulinum neurotoxin $B$ and a new FA mosaic type. Genome announce, 2(6): e01275-14, doi: 10.1128/ genomeA.01275-14

Gould IM, 2006. Costs of hospital-acquired methicillin-resistant Staphylococcus aureus (MRSA) and its control. Int J Antimicrob Agents 28(5): 379-384, doi: 10.1016/j.ijantimicag. 2006.09.001

Greeshma SS, Pillai D, Sebastian M and Joseph TC, 2021. Prevalence, antimicrobial resistance and virulence profile of Salmonella from aquaculture farms of central Kerala, India. Fishery Tech, 58(4): 239-245

Griffin MR, Dalley E, Fitzpatrick M and Austin SH, 1983. Campylobacter gastroenteritis associated with raw clams. J Med Soc NJ, 80(8): 607-609

Griffin PM and Tauxe RV, 1991. The epidemiology of infections caused by Escherichia coli O157: H7, other enterohemorrhagic E. coli, and the associated hemolytic uremic syndrome. Epidemiol Reviews, 13(1): 60-98

Guardiola-Avila I, Noriega-Orozco L, Acedo-Félix E, Lara AE and Tapia-Olea MM, 2015. Presence of 
the hemolysin gene of Vibrio mimicus in fish and seafood products in Sonora, México. J Food Res, 4(1): 66-76

Gufe C, Canaan HT, Mbonjani B, Majonga O, Marumure $\mathrm{J}$ et al., 2019. Antimicrobial profiling of bacteria isolated from fish sold at informal market in Mufakose, Zimbabwe. Int J Microbiol, 2019: 8759636, doi: 10.1155/2019/8759636

Hara-Kudo Y, Sugiyama K, Nishibuchi M, Chowdhury A, Yatsuyanagi J et al., 2003. Prevalence of pandemic thermostable direct hemolysin producing Vibrio parahaemolyticus O3:K6 in seafood and the coastal environment in Japan. Appl Environ Microbiol, 69(7): 3883-3891, doi: 10.1128/AEM.69.7.3883-3891.2003

Hassan R, Tecle S, Adcock B, Kellis M, Weiss J et al., 2018. Multistate outbreak of Salmonella paratyphi B variant L (+) tartrate $(+)$ and Salmonella weltevreden infections linked to imported frozen raw tuna: USA, March-July 2015. Epidemiol Infect, 146(11): 1461-1467, doi: $10.1017 /$ S0950268818001462

Hastein T, Hjeltnes B, Lillehaug A, Utne Skare J, Berntssen M et al., 2006. Food safety hazards that occur during the production stage: challenges for fish farming and the fishing industry. Rev Sci Tech, 25(2): 607-625

Hicks DT, 2016. Seafood safety and quality: The consumer's role. Foods, 5(4): 71 doi: 10.3390/ foods5040071

Huss HH, Reilly A and Embarek PKB, 2000. Prevention and control of hazards in seafood. Food control, 11(2): 149-156, doi: 10.1016/S09567135(99)00087-0

Ibarra J, Delgado A and Alvarado D, 1999. Vibrios no epidémicos y Vibrio cholerae $\mathrm{O} 1$ asociados a enfermedad diarreica aguda. Evento climatologico. "El Niño"-1998. Hospital Nacional Dos de Mayo. Ann Fac Med, Universidad Nacional Mayor de San Marcos, 60(4): 251-256

Igbinosa EO and Okoh AI, 2008. Emerging Vibrio species: An unending threat to public health in developing countries. Res Microbiol, 159(7-8): 495-506, doi: 10.1016/j.resmic.2008.07.001

Ishibashi M, Ohta K, Shimada T, Honda T, Sugiyama J et al., 2000. Current status of OK serotype combinations of Vibrio parahaemolyticus. Nippon Saikingaku Zasshi, 55(41): 103412

Iwamoto M, Ayers T, Mahon BE and Swerdlow DL, 2010. Epidemiology of seafood-associated infections in the United States. Clin Microbiol Rev, 23(2): 399-
411, doi: 10.1128/CMR.00059-09

Jami M, Ghanbari M, Zunabovic M, Domig KJ and Kneifel W, 2014. Listeria monocytogenes in aquatic food products - A review. Compr Rev Food Sci Food Saf, 13(5): 798-813, doi: 10.1111/ 1541-4337.12092

Jones JL, Lüdeke CH, Bowers JC, DeRosia-Banick K, Carey DH et al., 2014. Abundance of Vibrio cholerae, $V$. vulnificus, and $V$. parahaemolyticus in Oysters (Crassostreavirginica) and Clams (Mercenaria mercenaria) from Long Island Sound. Appl Environ Microbiol, 80(24): 76677672, doi: 10.1128/AEM.02820-14

Jones ME, Mayfield DC, Thornsberry C, Karlowsky JA, Sahm, DF et al., 2002. Prevalence of oxacillin resistance in Staphylococcus aureus among inpatients and outpatients in the United States during 2000. Antimicrob Agents Chemother, 46(9): 3104-3105, doi: 10.1128/AAC.46.9.31043105.2002

Joseph TC, Murugadas V, Reghunathan D, Shaheer P, Akhilnath PG et al., 2015. Isolation and characterization of Vibrio cholerae 0139 associated with mass mortality in Penaeus monodon and experimental challenge in post larvae of three species of shrimp. Aquaculture, 442: 44-47, doi: 10.1016/ j.aquaculture.2015.02.020

Kamat AS, Nerkar DP and Nair PM, 1989. Bacillus cereus in some Indian foods, incidence and antibiotic, heat and radiation resistance. J Food Saf, 10(1): 31-41, doi: 10.1111/j.17454565.1989.tb00005.x

Karunasagar I and Rohit A, 2012. Epidemiology and molecular pathogenesis of Vibrio vulnificus. In: Foodborne and Waterborne Bacterial Pathogens: Epidemiology, Evolution and Molecular Biology (Faruque SM, eds). Caister Academic Press, UK, pp 197

Kim YB, Kim ST, Lee SW, Jeen YT, Chun HJ et al., 2000. The influence of number of gastroscopic biopsy specimens on follow-up campylobacterlike organism (clo) test. Korean J Gastroenterol, 35(4): 422-428

Kishore P, Lalitha KV, Joseph TC and Thampuran N, 2012. Biotyping and antibiotic resistance profile of Yersinia enterocolitica associated with seafoods from South-West coast of India. Fishery tech, 49: 64-71

Kluytmans J, Van Leeuwen, Goessens W, Hollis R, Messer S et al., 1995. Food-initiated outbreak of methicillin-resistant Staphylococcus aureus 
analyzed by pheno-and genotyping. J Clin Microbiol, 33(5): 1121-1128, doi: 10.1128/ jcm.33.5.1121-1128.1995

Kumar HS, Otta SK, Karunasagar I and Karunasagar I, 2001. Detection of Shiga toxigenic Escherichia coli (STEC) in fresh seafood and meat marketed in Mangalore, India by PCR. Lett Appl Microbiol, 33(5): 334-338, doi: 10.1046/j.1472765X.2001.01007.x

Kumar R and Lalitha KV, 2013. Prevalence and molecular characterization of Vibrio cholerae $\mathrm{O} 1$, non-O1 and non-O139 in tropical seafood in Cochin, India. Foodborne Pathog Dis, 10(3): 278283, doi: 10.1089/fpd.2012.1310

Kumar R, Datta TK and Lalitha KV, 2015. Salmonella grows vigorously on seafood and expresses its virulence and stress genes at different temperature exposure. BMC Microbiol, 15(1): 1-10, doi: 10.1186/s12866-015-0579-1

Kumar R, Surendran PK and Thampuran N, 2009. Distribution and genotypic characterization of Salmonella serovars isolated from tropical seafood of Cochin, India. J Appl Microbiol, 106(2): 515-524, doi: 10.1111/j.1365-2672.2008 $.04020 . \mathrm{x}$

Kumar LRG, Kasim AK, Lekshmi, Nayak BB and Kumar S, 2016. Incidence of methicillinresistant Staphylococci in fresh seafood. Adv Microbiol, 6(6): 399-406, doi: 10.4236/ aim.2016.66039

Laishram M, Rathlavath S, Lekshmi M, Kumar S and Nayak BB, 2016. Isolation and characterization of Arcobacter spp. from fresh seafood and the aquatic environment. Int J Food Microbiol, 232: 87-89, doi: 10.1016/j.ijfoodmicro.2016.05.018

Lalitha KV and Gopakumar K, 2000. Distribution and ecology of Clostridium botulinum in fish and aquatic environments of a tropical region. Food Microbiol, 17(5): 535-541, doi: 10.1006/ fmic. 2000.0346

Lalitha KV and Gopakumar K, 2001. Growth and toxin production by Clostridium botulinum in fish (Mugil cephalus) and shrimp (Penaeus indicus) tissue homogenates stored under vacuum. Food Microbiol, 18(6): 651-657, doi: 10.1006/ fmic. 2001.0433

Lalitha KV and Surendran PK, 2002. Occurrence of Clostridium botulinum in fresh and cured fish in retail trade in Cochin (India). Int J Food Microbiol, 72(1-2): 169-174, doi: 10.1016/ S0168-1605(01)00632-8

Lee YC, Hor LI, Chiu HY, Lee JW and Shieh SJ, 2014.
Prognostic factor of mortality and its clinical implications in patients with necrotizing fasciitis caused by Vibrio vulnificus. Eur J Clin Microbiol Infect Dis, 33(6): 1011-1018, doi: 10.1007/ s10096-013-2039- $\mathrm{x}$

Levican A, Alkeskas A, Günter C, Forsythe SJ and Figueras MJ, 2013. Adherence to and invasion of human intestinal cells by Arcobacter species and their virulence genotypes. Appl Environ Microbiol, 79(16): 4951-4957, doi: 10.1128/ AEM.01073-13

Levican A, Collado L, Aguilar C, Yustes C, Diéguez AL et al., 2012. Arcobacter bivalviorum sp. nov. and Arcobacter venerupis sp. nov., new species isolated from shellfish. Syst Appl Microbiol, 35(3): 133138, doi: 10.1016/j.syapm.2012.01.002

Lindstrom M, Keto R, Markkula A, Nevas M, Hielm S et al, 2001. Multiplex PCR assay for detection and identification of Clostridium botulinum types $\mathrm{A}, \mathrm{B}, \mathrm{E}$, and $\mathrm{F}$ in food and faecal material. Appl Environ Microbiol, 67(12): 5694-5699, doi: 10.1128/AEM.67.12.5694-5699.2001

Lungu B, Ricke SC and Johnson MG, 2009. Growth, survival, proliferation and pathogenesis of Listeria monocytogenes under low oxygen or anaerobic conditions: A review. Anaerobe, 15(12): 7-17 doi: 10.1016/j.anaerobe.2008.08.001

Madiyal M, Eshwara V, Halim I, Stanley W, Prabhu M et al., 2016. A rare glimpse into the morbid world of necrotising fasciitis: Flesh-eating bacteria Vibrio vulnificus. Indian J Med Microbiol, 34(3): 384-386

Malau E, Ford R, Valcanis M, Jennison AV, Mosse J et al., 2018. Antimicrobial sensitivity trends and virulence genes in Shigella spp. from the Oceania region. Infect Genet Evol, 64: 52-56, doi: 10.1016/ j.meegid.2018.06.015

Manna SK, Brahmane MP, Manna C, Batabyal K and Das R, 2006. Occurrence, virulence characteristics and antimicrobial resistance of Escherichia coli O157 in slaughtered cattle and diarrhoeic calves in West Bengal, India. Lett Appl Microbiol, 43(4): 405-409, doi: 10.1111/j.1472-765X.2006 $.01975 . \mathrm{x}$

Martinez-Urtaza J, Saco M, de Novoa J, Perez-Piñeiro P, Peiteado J et al., 2004. Influence of environmental factors and human activity on the presence of Salmonella serovars in a marine environment. Appl Environ Microbiol, 70(4): 2089-2097, doi: 10.1128/AEM.70.4.2089-2097.2004

Matsumoto C, Okuda J, Ishibashi M, Iwanaga M, Garg P et al., 2000. Pandemic spread of an O3: K6 clone of Vibrio parahaemolyticus and emergence of 


\section{Seafoodborne pathogens and food safety}

related strains evidenced by arbitrarily primed PCR and toxRS sequence analyses. J Clin Microbiol, 38(2): 578-585, doi: 10.1128/ JCM.38.2.578-585.2000

Miranda N, Banerjee P, Simpson S, Kerdahi K and Sulaiman IM, 2017. Molecular surveillance of Cronobacter spp. isolated from a wide variety of foods from 44 different countries by sequence typing of $16 \mathrm{~S}$ rRNA, rpoB and $\mathrm{O}$-antigen genes. Foods, 6(5): 36, doi: 10.3390/foods 6050036

Moharem AS, Raj AC and Janardhana GR, 2007. Incidence of Listeria species in seafood products of Mysore, India. J Food Saf, 27(4): 362-372, doi: 10.1111/j.1745-4565.2007.00085.x

Momtaz H and Yadollahi S, 2013. Molecular characterization of Listeria monocytogenes isolated from fresh seafood samples in Iran. Diagnos Pathol, 8(1): 1-6, doi: 10.1186/ 1746-1596-8-149

Mortimer PR and McCann G, 1974. Food-poisoning episodes associated with Bacillus cereus in fried rice. Lancet, 303: 1043-1045, doi: 10.1016/ S0140-6736(74)90434-6

Murugadas V, Joseph TC and Lalitha KV, 2015. Distribution of pathotypes of Escherichia coli in seafood from retail markets of Kerala, India. Indian J Fish, 63(1): 152-155

Murugadas V, Joseph TC and Lalitha KV, 2017. Tracing contamination of Methicillin-resistant Staphylococcus aureus (MRSA) into seafood marketing chain by Staphylococcal protein A typing. Food Control, 78: 43-47, doi: 10.1016/ j.foodcont.2017.02.028

Murugadas V, Joseph TC, Reshmi K and Lalitha KV, 2016. Prevalence of methicillin resistant Staphylococcus aureus in selected seafood markets and aquaculture farms in Kerala, South-West coast of India. J Environ Biol, 3(4): 150-153

Nadella RK, Murugadas V, Joseph TC, Lalitha KV, Basha KA et al., 2019. Need for an optimized protocol for screening seafood and aquatic environment for Shigella spp. Fishery tech, 56: 164-167

Nair GB, Faruque SM, Bhuiyan NA, Kamruzzaman M, Siddique AK et al., 2002. New variants of Vibrio cholerae $\mathrm{O} 1$ biotype El Tor with attributes of the classical biotype from hospitalized patients with acute diarrhea in Bangladesh. J Clin Microbiol, 40(9): 3296-3299, doi: 10.1128/ JCM.40.9.3296-3299.2002

Nair GB, Ramamurthy T, Bhattacharya SK, Dutta B,
Takeda Y et al., 2007. Global dissemination of Vibrio parahaemolyticus serotype O3:K6 and its serovariants. Clin Microbiol Rev, 20: 39-48, doi: 10.1128/CMR.00025-06

Nair GB, Ramamurthy T, Sur D, Kurakawa T, Takahashi $\mathrm{T}$ et al., 2012. Vibrio cholerae/mimicus in fecal microbiota of healthy children in a cholera endemic urban slum setting in Kolkata, India. Microbiol Immunol, 56(11): 789-791, doi: 10.1111/j.1348-0421.2012.00497.x

Narayanan SV, Joseph TC, Peeralil S, Mothadaka MP and Lalitha KV, 2020a. Prevalence, virulence characterization, AMR pattern and genetic relatedness of Vibrio parahaemolyticus isolates from retail seafood of Kerala, India. Front Microbiol, 11: 592, doi: 10.3389/fmicb. 2020.00592

Narayanan SV, Joseph TC, Peeralil S, Koombankallil R, Vaiyapuri M et al., 2020b. Tropical shrimp aquaculture farms harbour pathogenic Vibrio parahaemolyticus with high genetic diversity and Carbapenam resistance. Mar Pollut Bull, 160: 111551, doi: 10.1016/j.marpolbul.2020.111551

Newell DG, Koopmans M, Verhoef L, Duizer E, AidaraKane A et al., 2010. Food-borne diseases-the challenges of 20 years ago still persist while new ones continue to emerge. Int $\mathrm{J}$ Food Microbiol, 139: S3-S15, doi: 10.1016/ j.ijfoodmicro.2010.01.021

Nilavan E, Vaiyapuri M, Sadanandan SG, Nadella RK, Thandapani M et al., 2021. Prevalence of Vibrio mimicus in fish, fishery products, and environment of South West Coast of Kerala, India. J AOAC Int, 104(3): 790-794, doi: 10.1093/ jaoacint/qsab001

Niyogi SK, 2005. Shigellosis. J Microbiol, 43(2): 133143

Norhana MW, Poole SE, Deeth HC and Dykes GA, 2010. Prevalence, persistence and control of Salmonella and Listeria in shrimp and shrimp products: A review. Food Control, 21(4): 343361, doi: 10.1016/j.foodcont.2009.06.020

O'Connor L, O'leary M, Leonard N, Godinho M, O'Reilly C et al., 2010. The characterization of Listeria spp. isolated from food products and the food processing environment. Lett Appl Microbiol, 51(5): 490-498, doi: 10.1111/j.1472765X.2010.02928.x

Obaidat MM and Salman AEB, 2017. Antimicrobial resistance percentages of Salmonella and Shigella in seafood imported to Jordan: Higher percentages and more diverse profiles in Shigella. J Food Prot, 80(3): 
414-419, doi: 10.4315/0362-028X.JFP-16-322

Okuda J, Ishibashi M, Abbott SL, Janda JM and Nishibuchi M, 1997. Analysis of the thermostable direct hemolysin $(t d h)$ gene and the $t d h$ related hemolysin $(t r h)$ genes in urease-positive strains of Vibrio parahaemolyticus isolated on the West Coast of the United States. J Clin Microbiol, 35: 19651971, doi: 10.1128/jcm.35.8.1965-1971.1997

Oliver JD and Kaper JB, 1997. Vibrio species. In: Food Microbiology: Fundamentals and Frontiers (Doyle MP, Beuchat LR, Montville TD, Eds). ASM Press, Washington DC, USA, pp 228-264

Pal D and Das N, 2010. Isolation, identification and molecular characterization of Vibrio parahaemolyticus from fish samples in Kolkata. Eur Rev Med Pharmaco, 14(6): 545-549

Parihar VS, Barbuddhe SB, Danielsson-Tham ML and Tham W, 2008. Isolation and characterization of Listeria species from tropical seafoods. Food Control, 19(6): 566-569, doi: 10.1016/ j.foodcont.2007.06.009

Parlapani FF, Meziti A, Kormas KA and Boziaris IS, 2013. Indigenous and spoilage microbiota of farmed sea bream stored in ice identified by phenotypic and 16S rRNA gene analysis. Food Microbiol, 33(1): 85-89, doi: 10.1016/ j.fm.2012.09.001

Pazhani GP, Bhowmik SK, Ghosh S, Guin S, Dutta S et al., 2014. Trends in the epidemiology of pandemic and non-pandemic strains of Vibrio parahaemolyticus isolated from diarrheal patients in Kolkata, India. PLOS Negl Trop Dis, 8(5): 110, doi: 10.1371/journal.pntd.0002815

Pei J, Wang H, Wu L, Xia S, Xu C et al., 2017. Biochemical characterization of a Catalase from Vibrio vulnificus, a pathogen causing gastroenteritis. Acta Biochimica Polonica, 64(3): 543-549, doi: 10.18388/abp.2017_1530

Peng FM, Jiang DY, Ruan HH, Liu HQ and Zhou LP, 2010. Pathogenic investigation on a food poisoning induced by Vibrio parahaemolyticus. Prev Med Trib, 16: 746-747

Phillips KE and Satchell KJ, 2017. Vibrio vulnificus: from oyster colonist to human pathogen. PLoS Pathogens, 13(1): e1006053, doi: 10.1371/ journal.ppat. 1006053

Poblete R, Andresen M, Pérez C, Dougnac A, Díaz O et al., 2002. Vibrio vulnificus: una causa infrecuente de shock séptico. Rev Méd Chile, 130(7): 787-791, doi: 10.4067/S003498872002000700011

Poli BM, 2005. Quality and certification of fishery products from both capture and farming. Interactions between aquaculture and capture fisheries: A methodological perspective, (78): 144

Prabhakar P, Lekshmi M, Ammini P, Nayak BB and Kumar S, 2020. Salmonella contamination of seafood in landing centers and retail markets of Mumbai, India. J AOAC Int, 103(5): 1361-1365, doi: 10.1093/jaoacint/qsaa042

Rahmati T and Labbe R, 2008. Levels and toxigenicity of Bacillus cereus and Clostridium perfringens from retail seafood. J Food Prot, 71(6): 1178-1185, doi : 10.4315/0362-028X-71.6.1178

Ramees TP, Dhama K, Karthik K, Rathore RS, Kumar A et al., 2017. Arcobacter: An emerging foodborne zoonotic pathogen, its public health concerns and advances in diagnosis and controlA comprehensive review. Vet Quarter, 37(1): 136161, doi: 10.1080/01652176.2017.1323355

Rao MB, Viji P, Jesmi D, Prasad MM and Ravishankar CN, 2017. Quality concerns of Indian fishery exports as indicated by the import alerts by European Union and the United States: steps to mitigate recurrence. Fish Chimes, 36(10): 34-43

Rhee $\mathrm{CH}$ and Woo GJ, 2010. Emergence and characterization of foodborne methicillinresistant Staphylococcus aureus in Korea. J Food Prot, 73(12): 2285-2290, doi: 10.4315/0362028X-73.12.2285

Rincee A, Balière C, Hervio-Heath D, Cozien J, Lozach S et al., 2018. Occurrence of bacterial pathogens and human noroviruses in shellfish-harvesting areas and their catchments in France. Front Microbiol, 9: 2443, doi: 10.3389/fmicb.2018.02443

Rippey SR, 1994. Infectious diseases associated with molluscan shellfish consumption. Clin Microbiol Rev, 7(4): 419-425, doi: 10.1128/CMR.7.4.419

Rocourt J, Benembarek P, Toyofuku H and Schlundt J, 2003. Review. Quantitative risk assessment of Listeria monocytogenes in ready-to-eat foods: the FAO/WHO approach. FEMS Immunol Med Microbiol, 35(3): 263-267, doi: 10.1016/S09288244(02)00468-6

Romero J, García-Varela M, Laclette JP and Espejo RT, 2002. Bacterial 16S rRNA gene analysis revealed that bacteria related to Arcobacter spp. constitute an abundant and common component of the oyster microbiota (Tiostrea chilensis). Microb Ecol, 44(4): 365-371, doi: 10.1007/s00248-002-1063-7

Ronzio RA, 2003. The encyclopedia of nutrition and good health. Infobase Publishing

Roy D, Biswas B, Islam HM, Ahmed MS, 
Rasheduzzaman M et al., 2013. Rapid identification of enterovirulent Escherichia coli strains using polymerase chain reaction from shrimp farms. Pak J Biol Sci, 16(21): 1260-1269, doi: $10.3923 /$ pjbs.2013.1260.1269

Safa A, Bhuyian NA, Nusrin S, Ansaruzzaman M, Alam $\mathrm{M}$ et al., 2006. Genetic characteristics of Matlab variants of Vibrio cholerae $\mathrm{O} 1$ that are hybrids between classical and El Tor biotypes. J Med Microbiol, 55(11): 1563-1569, doi: 10.1099/ jmm.0.46689-0

Samadi AR, Chowdhury MK, Huq MI and Khan MU, 1983. Seasonality of classical and El Tor cholera in Dhaka, Bangladesh: 17-year trends. Trans R Soc Trop Med Hyg, 77(6): 853-856, doi: 10.1016/ 0035-9203(83)90306-1

Saraswathi K, Barve SM and Deodhar LP, 1989. Septicaemia due to Vibrio vulnificus. Trans R Soc Trop Med Hyg, 83(5): 714-714, doi: 10.1016/ 0035-9203(89)90406-9

Saravanan V, Kumar HS, Karunasagar I and Karunasagar I, 2007. Putative virulence genes of Vibrio cholerae from seafoods and the coastal environment of Southwest India. Int J Food Microbiol, 119(3): 329-333, doi: 10.1016/ j.ijfoodmicro.2007.08.023

Scallan E, Griffin PM, Angulo FJ, Tauxe RV and Hoekstra RM, 2011. Foodborne illness acquired in the United States unspecified agents. Emerg Infect Dis, 17(1): 16-22, doi: 10.3201/ eid1701.P21101

Schmid PJ, Maitz S and Kittinger C, 2021. Bacillus cereus in packaging material: molecular and phenotypical diversity revealed. Front Microbiol, 12: 1-11, doi: 10.3389/fmicb.2021.698974

Sechi LA, Duprè I, Deriu A, Fadda G and Zanetti S, 2000. Distribution of Vibrio cholerae virulence genes among different Vibrio species isolated in Sardinia, Italy. J Appl Microbiol, 88(3): 475-481, doi: 10.1046/j. 1365-2672.2000.00982.x

Setti I, Rodriguez-Castro A, Pata MP, Cadarso-Suarez C, Yacoubi B et al., 2009. Characteristics and dynamics of Salmonella contamination along the coast of Agadir, Morocco. Appl Environ Microbiol, 75(24): 7700-7709, doi: 10.1128/ AEM.01852-09

Shanmugapriya S, Senthilmurugan $\mathrm{T}$ and Thayumanavan T, 2014. Genetic diversity among Yersinia enterocolitica isolated from chicken and fish in and around Coimbatore City, India. Iran J Public Hlth, 43(6): 835-844

Sheng L and Wang L, 2021. The microbial safety of fish and fish products: Recent advances in understanding its significance, contamination sources and control strategies. Compr Rev Food Sci Food Saf, 20(1): 738-786, doi: 10.1111/15414337.12671

Shukla HD and Sharma SK, 2005. Clostridium botulinum: a bug with beauty and weapon. Crit Rev Microbiol, 31(1): 11-18, doi: 10.1080/ 10408410590912952

Simental L and Martinez-Urtaza J, 2008. Climate patterns governing the presence and permanence of Salmonella in coastal areas of Bahia de Todos Santos, Mexico. Appl Environ Microbiol, 74(19): 5918-5924, doi: 10.1128/AEM.01139-08

Simon SS and Sanjeev S, 2007. Prevalence of enterotoxigenic Staphylococcus aureus in fishery products and fish processing factory workers. Food Control, 18(12): 1565-1568, doi: 10.1016/j.foodcont.2006.12.007

Simonova J, Vazlerova M and Steinhauserova I, 2007. Detection of pathogenic Yersinia enterocolitica serotype O: 3 by biochemical, serological and PCR methods. Czech J Food Sci, 25(4): 214-220

Singh K and Basudha C, 2021. Economics and resource use efficiency of small-scale fish production in Manipur. Fishery Technol, 58(3): 177-186

Singh N, Goel G and Raghav M, 2015. Prevalence and characterization of Cronobacter spp. from various foods, medicinal plants, and environmental samples. Curr Microbiol, 71(1): 31-38, doi: 10.1007/s00284-015-0816-8

Sinha I, Choudhary I and Virdi JS, 2000. Isolation of Yersinia enterocolitica and Yersinia intermedia from wastewaters and their biochemical and serological characteristics. Curr Sci, 79(4): 510513

Stanley K and Jones K, 2003. Cattle and sheep farms as reservoirs of Campylobacter. J Appl Microbiol, 94: 104-113, doi: 10.1046/j.13652672.94.s1.12.X

Su YC and Liu C, 2007. Vibrio parahaemolyticus: A concern of seafood safety. Food Microbiol, 24(6): 549-558, doi: 10.1016/j.fm.2007.01.005

Sudha S, Mridula C, Silvester R and Hatha AAM, 2014. Prevalence and antibiotic resistance of pathogenic Vibrios in shellfishes from Cochin market. Indian J Geo-Mar Sci, 43(5): 815-824

Sujatha K, Senthilkumaar P, Sangeetha S and Gopalakrishnan MD, 2011. Isolation of human pathogenic bacteria in two edible fishes, Priacanthus hamrur and Megalaspis cordyla at Royapuram waters of Chennai, India. Indian J Sci Technol, 4(5): 539-541 
Sukumaran D and Hatha AAM, 2015. Antibiotic resistance and virulence genes of extraintestinal pathogenic Escherichia coli from tropical estuary, South India. JIDC, 9(05): 496-504, doi: 10.3855/ jidc. 5627

Surendraraj A, Thampuran N and Joseph TC, 2010. Molecular screening, isolation, and characterization of enterohemorrhagic Escherichia coli O157: H7 from retail shrimp. J Food Prot, 73(1): 97-103, doi: 10.4315/0362028X-73.1.97

Tewari A, Singh SP and Singh R, 2015. Incidence and enterotoxigenic profile of Bacillus cereus in meat and meat products of Uttarakhand, India. J Food Sci Technol, 52(3): 1796-1801, doi: 10.1007/ s13197-013-1162-0

Thampuran N and Surendran PK, 1998. Occurrence and distribution of Vibrio vulnificus in tropical fish and shellfish from Cochin, India. Lett Appl microbiol, 26(2): 110-112, doi: 10.1046/j.1472765x.1998.00286.x

Thampuran N, Surendraraj A and Surendran PK, 2005. Prevalence and characterization of typical and atypical Escherichia coli from fish sold at retail in Cochin, India. J food Prot, 68(10): 2208-2211, doi: 10.4315/0362-028X-68.10.2208

Thiaville PC, Bourdage KL, Wright AC, Farrell-Evans M, Garvan CW et al. 2011. Genotype is correlated with but does not predict virulence of Vibrio vulnificus Biotype 1 in subcutaneously inoculated, iron dextran-treated mice. Infect Immun, 79: 11941207, doi: 10.1128/IAI.01031-10

Toma C, Lu Y, Higa N, Nakasone N, Chinen I et al., 2003. Multiplex PCR assay for identification of human diarrheagenic Escherichia coli. J Clin Microbiol, 41(6): 2669-2671, doi: 10.1128/ JCM.41.6.2669-2671.2003

USFDA (United State Food and Drug Administration), 2008. Bad bug book. Foodborne pathogenic microorganisms and natural toxins handbook. Available in www.cfsan.fda.gov/mow/intro.html

Vazquez-Boland JA, Kuhn M, Berche P, Chakraborty T, Domýìnguez-Bernal G et al., 2001. Listeria pathogenesis and molecular virulence determinants. Clin Microbiol Rev, 14(3): 584640, doi: 10.1128/CMR.14.3.584-640.2001

Vemula SR, Kumar RN and Polasa K, 2012. Foodborne diseases in India - A review. Br Food J, 114(5): 661-680 doi: 10.1108/00070701211229954

Villacrés D, Díaz LI, Herrera P, Naranjo F, Vargas AC et al., 2013. Sepsis por Vibrio vulnificus: reporte de dos casos en ciudades de altura en el Ecuador. VozAndes, pp 53-58

Visnuvinayagam S, Murthy LN, Viji P and Sivaraman GK, 2017. Study on retail fish markets: Possible occurrence and transmission of emerging pathogen from faecal indicators. JEB, 38: 465-470

Visnuvinayagam S, Joseph TC, Murugadas V, Chakrabarti R and Lalitha KV, 2015. Status on methicillin resistant and multiple drug resistant Staphylococcus aureus in fishes of Cochin and Mumbai coast, India. JEB, 36(3): 571-575

Wang F, Jiang L, Yang Q, Han F, Chen S et al., 2011. Prevalence and antimicrobial susceptibility of major foodborne pathogens in imported seafood. J Food Prot, 74(9): 1451-1461, doi: 10.4315/0362028X.JFP-11-146

Wang H, Yang C, Sun Z, Zheng W, Zhang W et al., 2020. Genomic epidemiology of Vibrio cholerae reveals the regional and global spread of two epidemic non-toxigenic lineages. PLoS Neg Trop Dis, 14(2): e0008046, doi: 10.1371/ journal.pntd.0008046

WHO, 2015. World Health Statistic 2015. Vol 16 , WHO

Wilkes G, Edge TA, Gannon VP, Jokinen C, Lyautey E et al., 2011. Associations among pathogenic bacteria, parasites, and environmental and land use factors in multiple mixed-use watersheds. Water Res, 45(18): 5807-5825, doi: 10.1016/j.watres.2011.06.021

Wilson IG and Moore JE, 1996. Presence of Salmonella spp. and Campylobacter spp. in shellfish. Epidemiol Infect, 116(2): 147-153, doi: 10.1017/S0950268800052377

Wingstrand A, Neimann J, Engberg J, Nielsen EM, Gerner-Smidt P et al., 2006. Fresh chicken as main risk factor for Campylobacteriosis, Denmark. Emerg Infect Dis, 12(2): 280-284, doi: 10.3201/eid1202.050936

Xu X, Cheng J, Wu Q, Zhang J and Xie T, 2016. Prevalence, characterization, and antibiotic susceptibility of Vibrio parahaemolyticus isolated from retail aquatic products in North China. BMC Microbiol, 16(1): 321-329, doi: 10.1186/s12866-016-0650-6

Zhang X, Alter T and Gölz G, 2019. Characterization of Arcobacter spp. isolated from retail seafood in Germany. Food microbiol, 82: 254-258, doi: 10.1016/j.fm.2019.02.010

Received - 16.10.2021, Accepted - 27.11.2021, Published - 01.12.2021

Section Editor: Prof. S. K. Das, Member, Editorial Board 